\title{
Species Composition of Genus Calyptogena in Sagami Bay: A Morphology-based Study
}

\author{
Kenji Ito \\ National Agricultural Research Center, Insect Ecology Laboratory, Kannondai 3-I-I, \\ Tsukuba, Iharaki 305-8666, Japan
}

\begin{abstract}
The species composition of two species in genus Calyptogena, $C$. soyoae and C. okutanii, was examined in three areas in Sagami Bay. Species were identified based on shell morphology. The dominant species in cold-seepage sites Off Hatsushima Island (OHI) and at the Okinoyama Bank (OB) was C. okutanii (74.4 and $60.5 \%$, respectively). However, most Calyptogena at the Sagami Knoll (SK) were C. soyoae (90.7\%). The proportion of these two Calyptogena species differed significantly among the three seepage sites. Given that most ecological studies of Calyptogena have been conducted at the OHI cold-seepage site, these results suggest that most of the ecological information on Calyptogena in Sagami Bay is derived not from C. soyoae but from C. okutanii.
\end{abstract}

Key words: Calyptogena okutanii, Calyptogena soyoae, chemosynthetic community, species composition

\section{INTRODUCTION}

Bivalves of the genus Calyptogena are one of the dominant groups within chemosynthetic communities (Lutz 1993). Many researchers have conducted ecological and physiological studies of these species in various hydrothermal vents and cold-seepage areas (Turekian \& Cochran 1981; Endow \& Ohta 1990; Barry et al. 1997; Kojima \& Ohta 1997a; Lisin et al. 1997). In deep waters off Japan, numerous Calyptogena species have been described and studied (Okutani et al. 2000; Kojima 2002). The first population of Calyptogena species was described from Sagami Bay in Japan; a large population of Calyptogena was found at a depth around 1,100 $\mathrm{m}$ at a cold-seepage site off Hatsushima Island (OHI) in Sagami Bay during submersible dives in 1984 (Okutani \& Egawa 1985). Since that discovery, smaller Calyptogena populations have been discovered in other locations in Sagami Bay, such as the Okinoyama Bank (OB; Hashimoto et al. 1988) and the Sagami Knoll (SK; Hattori et al. 1993).

In population biology, correct species identification is indispensable; when the classification criteria of a

Received Nov. 17, 2003: Accepted Dec. 13, 2004 species are re-examined, ecological findings of the species may also need to be re-examined. Ecological studies have been conducted on the Calyptogena populations in Sagami Bay (e.g., Hashimoto et al. 1995; Fujiwara et al. 1998). In these studies, it was presumed that the populations consisted of a single species, $C$. soyoae, which had been described based on the morphological findings of dead shells (Okutani 1957). However, Kojima and coworkers discovered that the Calyptogena populations of Sagami Bay included two mitochondrial DNA haplotypes (Kojima et al. 1995a, 1995b). Kojima \& Ohta (1997b) revealed that the two haplotypes were discriminated also by a morphological characteristic (the lengthheight ratio of the shell), and described one haplotype as a new species, C. okutanii. When re-examining the result of this earlier study of Calyptogena in Sagami Bay, it is important to measure the species ratio of the two Calyptogena species. However, there is little information about the coexistence of the two species.

The main aim of this study was to examine the species composition of the two Calyptogena species in three local populations in Sagami Bay (OHI, SK, and OB), based on the shell morphology described by Kojima \& Ohta (1997b). Based on the results, we discussed whether the given information on Calyptogena in Sagami Bay was derived from $C$. soyoae or C. okutanii. In addi- 
tion, growth-related changes in shell morphology were also examined. Kojima \& Ohta (1997b) assume that the key characteristic of the morphological classification (the length-height ratio of the shell) does not change with shell growth; however, this assumption has not been examined yet.

\section{MATERIALS AND METHODS}

The shells of $C$. okutanii in Sagami Bay are narrower than those of $C$. soyoae; the length-height ratios are $2.19 \pm 0.10$ and $1.98 \pm 0.11$, respectively (Kojima \& Ohta 1997b). Based on that previous morphological description, we assumed that specimens with a length-height ratio greater than 2.09 were $C$. okutanii.

Specimens of Calyptogena were collected from three sites (OHI, SK, and OB) in Sagami Bay from 1987 to 1997 using submersible and ROV surveys conducted by the Japan Marine Science and Technology Center (Fig. 1). All Calyptogena specimens were alive when collected. Most of these specimens were fixed with formalin or ethanol, and some were preserved as dried shells. Kojima \& Ohta (1997b) did not use small specimens (shell length $<55 \mathrm{~mm}$ ) in their description, and the smaller shells of Calyptogena in Sagami Bay had a rounder shape than that of the larger shells (see Results). Therefore, we selected and analyzed specimens with shell lengths greater than $55 \mathrm{~mm}$, for a total of 253 specimens: 172 specimens from OHI, 43 specimens from SK, and 38 specimens from OB. Sampling location and date, number of samples, and dive number are presented in Table 1.

Shell length and height were measured using a slide caliper to the nearest $0.01 \mathrm{~mm}$ (Fig. 2). Based on the shell-ratio criterion for the classification of $C$. soyoae and C. okutanii, the proportion of each species was estimated at each site. To evaluate the difference in species composition of Calyptogena among the sites, we used the chisquared test with Tukey-type multiple comparisons (Zar 1999).

To examine the effect of body growth on the key characteristic of the morphological classification, we compared the shell length-height ratios between the young and old growth stages in the same individual. We selected 15 subsamples from the specimens collected from $\mathrm{OHI}$ and SK, respectively. There were many growth rings on the shell surface in each specimen. We selected two external rings on the shell surface (shell length: small ring, 36.1-62.5 mm; large ring, 72.6-111.7 mm)

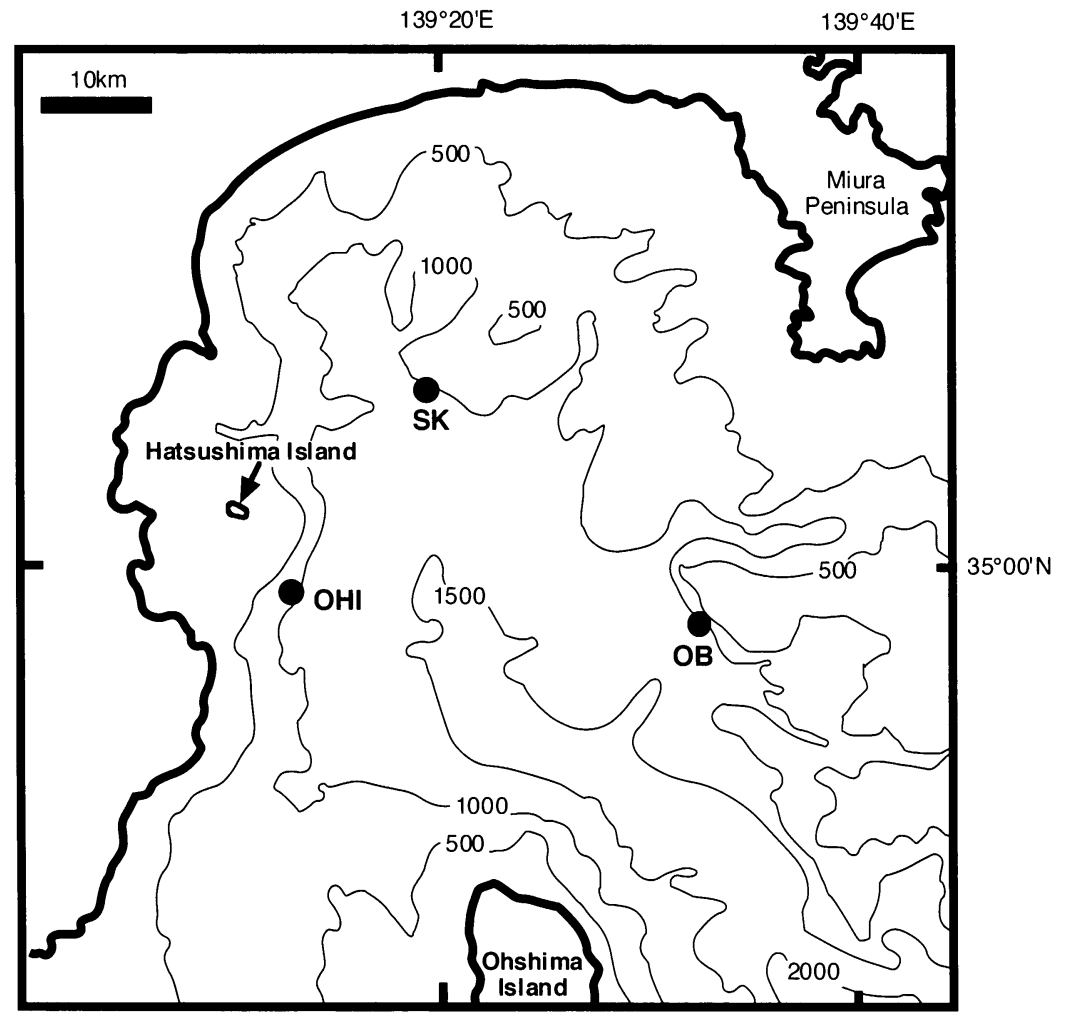

Fig. 1. Locations where samples were collected in Sagami Bay: (OHI) Off Hatsushima Island; (OB) Okinoyama Bank; (SK) Sagami Knoll. Depths are in meters. 
Table 1. List of samples used in the present study.

\begin{tabular}{|c|c|c|c|c|}
\hline Location & Sampling Date & Submersible & Dive No. & No. of samples \\
\hline \multirow[t]{9}{*}{ Off Hatsushima } & 1989.10 .21 & Shinkai 2000 & 450 & 22 \\
\hline & 1989.10 .22 & Shinkai 2000 & 451 & 67 \\
\hline & 1990.7 .13 & Dolphin $3 K$ & 78 & 15 \\
\hline & 1990.11 .11 & Shinkai 2000 & 518 & 5 \\
\hline & 1990.11 .12 & Shinkai 2000 & 519 & 9 \\
\hline & 1993.4 .9 & Shinkai 2000 & 667 & 3 \\
\hline & 1995.4 .20 & Dolphin $3 K$ & 211 & 5 \\
\hline & 1997.5.27 & Dolphin $3 K$ & 321 & 42 \\
\hline & 1997.5.29 & Dolphin $3 K$ & 324 & 4 \\
\hline \multirow[t]{5}{*}{ Okinoyama Bank } & 1987.5.17 & Dolphin $3 K$ & 45 & 17 \\
\hline & 1987.5.22 & Shinkai 2000 & 278 & 7 \\
\hline & 1988.6.11 & Dolphin $3 K$ & 29 & 1 \\
\hline & 1988.10 .11 & Dolphin $3 K$ & 38 & 8 \\
\hline & 1990.7 .12 & Dolphin $3 K$ & 75 & 5 \\
\hline \multirow[t]{2}{*}{ Sagami Knoll } & 1991.11 .15 & Shinkai 2000 & 583 & 5 \\
\hline & 1993.11 .6 & Dolphin $3 K$ & 166 & 38 \\
\hline
\end{tabular}

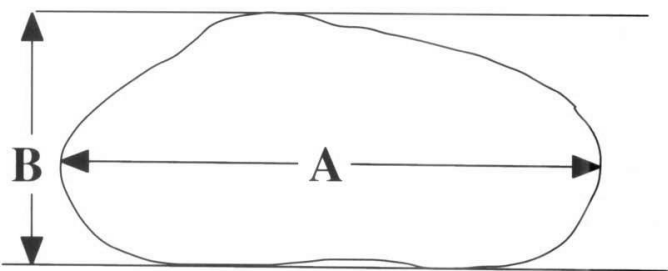

Fig. 2. Measurement of (A) shell length and (B) shell height of Calyptogena.

and measured the length and height of the rings individually. For each individual, we compared the ratio of length and height between the small and the large rings using Wilcoxon's signed-rank test.

All statistical tests were performed at a $p<0.05 \mathrm{sig}-$ nificance level.

\section{RESULTS}

The frequency distributions of the length-height ratio of the shells were different among the sites (Fig. 3). Specimens from OHI and SK had a single peak in the 2.20-2.25 and 2.0-2.05 classes, respectively, and specimens from OB had two peaks, one at the 2.05-2.10 class and one at the $2.25-2.30$ class. In this study, we assumed that specimens with a length-height ratio greater than 2.09 were C. okutanii (see Materials and Methods). Table 2 shows species ratio of two Calyptogena species based on this criterion. The ratios of the two Calyptogena species were significantly different at SK compared to the other two sites. The dominant species of Calyptogena at $\mathrm{OHI}$ and $\mathrm{OB}$ was $C$. okutanii, whereas the majority of
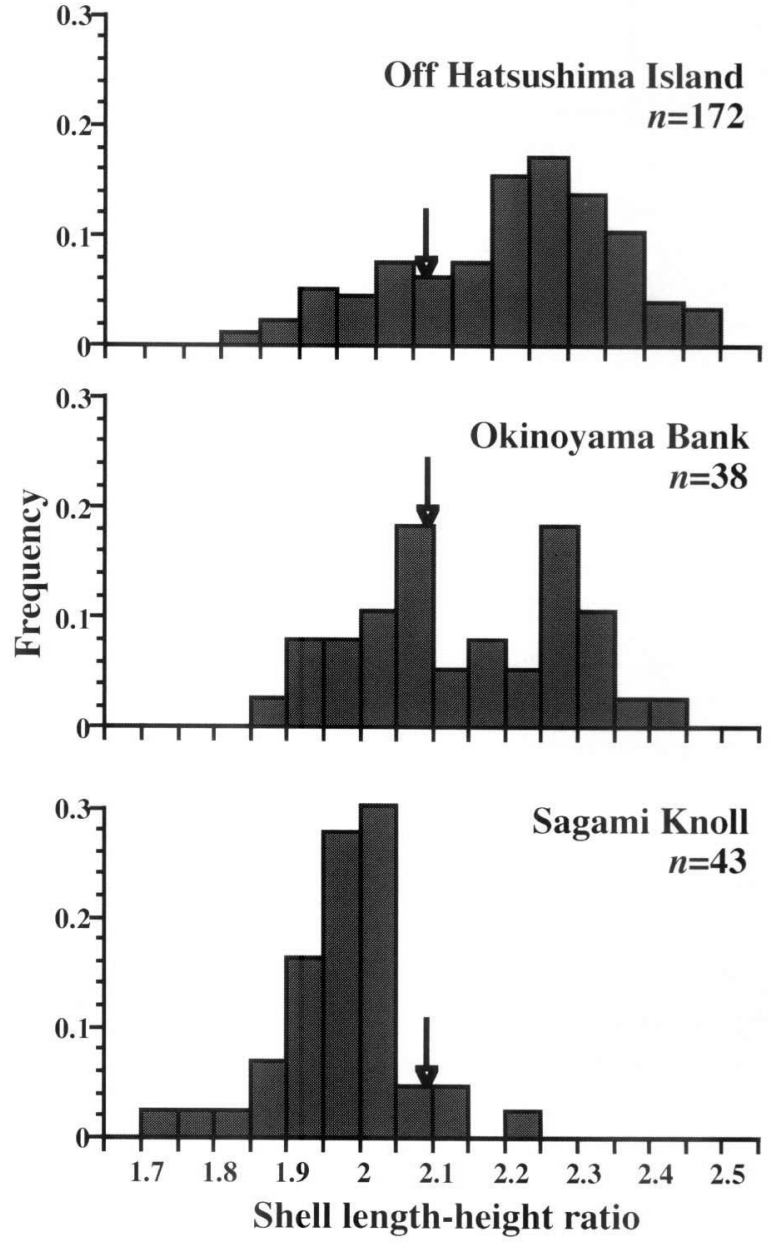

Fig. 3. Frequency distribution of shell length-height ratio of Calyptogena in three seep sites in Sagami Bay. Black arrows denote the criteria of classification between $C$. soyoae and C. okutanii (shell length-height ratio $=2.09$, see Materials and Methods) 


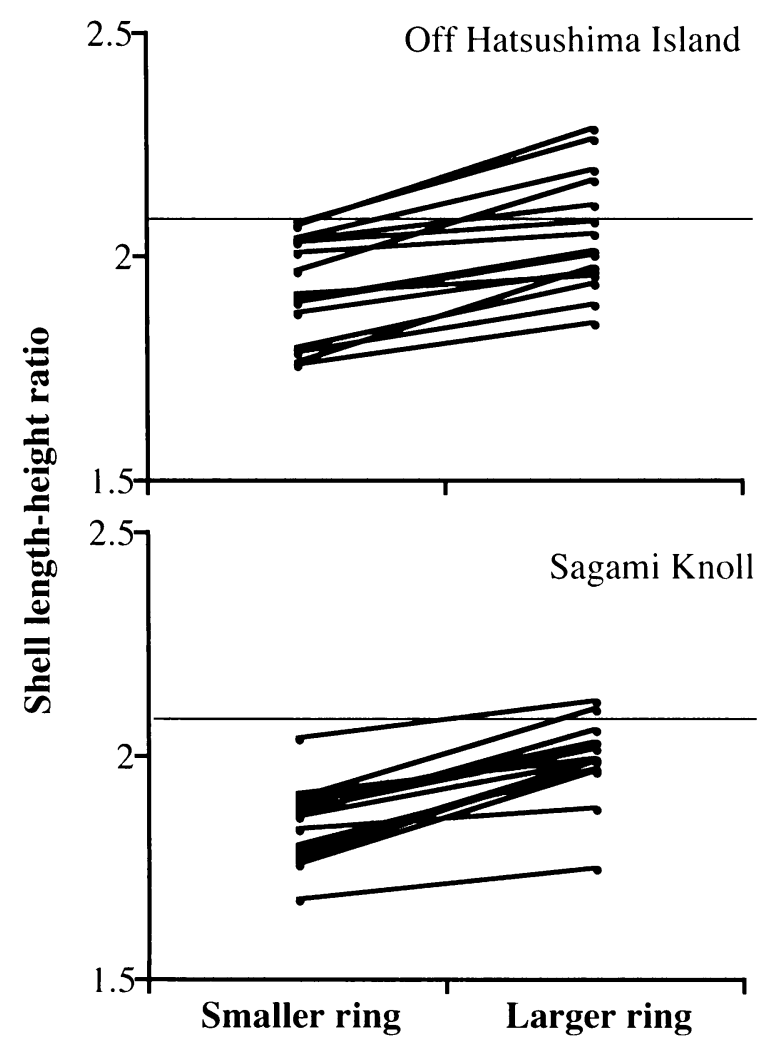

Fig. 4. Comparison of length-height ratio of larger and smaller rings of Calyptogena in Sagami Bay. Horizontal lines denote the criteria of classification between $C$. soyocae and $C$. okutanii (shell length-height ratio $=2.09$, see Materials and Methods). The value of large ring is significantly higher than small ring (Wilcoxon's sign rank test, $p<0.0(0) 1$ ).

\section{Calyptogena at SK were $C$. soyoae.}

In the analysis above, we assume, following Kojima \& Ohta (1997b), that the key characteristic of the morphological classification (the length-height ratio of the shell) does not change through life. To examine the stability of morphological-classification criterion in this study, the length-height ratios were compared between small and large rings (Fig. 4). At SK and $\mathrm{OHI}$, the length-height ratios of the large rings (i.e., older stages) were significantly higher than those of the small rings (younger stages; Fig. 4). Some of the length-height ratio of large rings ( $>72.6 \mathrm{~mm}$; five of 15 samples from $\mathrm{OHI}$ and two of 15 samples from SK) was more than 2.09. However, all of the length-height ratios of small rings $(<62.3 \mathrm{~mm}$ shell length) were less than 2.09 .

\section{DISCUSSION}

Our morphological data suggest that the Calyptogena populations at $\mathrm{OB}$ and $\mathrm{OHI}$ were composed mainly
Table 2. Number of $C$. soyoae and $C$. okutanii in samples of Calyptogena from sites in Sagami Bay. There were significant differences in species ratio among the sites $\left(\chi^{2}=61.474, \mathrm{df}=2\right.$, $p<0.001)$. Off Hatsushima Island $(\mathrm{OHI})=$ Okinoyama Bank $(\mathrm{OB}) \neq$ Sagami Knoll (SK).

\begin{tabular}{lrcr}
\hline & \multicolumn{3}{c}{ Sampling sites } \\
\hline & OHI & OB & SK \\
\hline C. soyoae & 44 & 15 & 39 \\
C. okutanii & 128 & 23 & 4 \\
\hline
\end{tabular}

of C. okutanii, and that most Calyptogena collected at SK were $C$. soyoae (Table 2). This trend supports the data in a report by Kojima \& Ohta (1997b) based on molecular analysis: 13 of 22 samples collected from $\mathrm{OHI}$ and 11 of 13 samples collected from OB were classified as $C$. okutanii, and all three samples collected from SK were classified as $C$. soyoae. This concordance between morphological and molecular data implies that the true species composition is reflected in the frequency distribution of shell length-height ratios (Fig. 3). To better understand the difference in Calyptogena species composition among the sites, it may be effective to compare SK and the other cold-seepage areas in terms of the environment of the Calyptogena population. However, habitat description and ecological studies of Calyptogena have not been fully conducted at SK.

Calyptogena okutanii has been found in a wide area around Japan (seepage areas of Sagami Bay, the Ryuyo Canyon, the Nankai Trough and around hydrothermal vents of Iheya Ridge, the Okinawa Trough), whereas $C$. soyoae has been collected only in Sagami Bay (Kojima 2002). In Sagami Bay, C. soyoae is dominant only in a small local population of SK (Table 2). These results imply that, compared with $C$. okutanii, the environmental conditions in which $C$. soyoae can survive are restricted.

Shell shape of Calyptogena species in Sagami Bay tends to become slender with growth (Fig. 4), a pattern reported in Sagami Bay by Horikoshi \& Hashimoto (1992) and Hattori et al. (1993). It is likely that this morphological change occurs in both $C$. okutanii and $C$. soyoae because this growth pattern was observed in samples taken from SK and OHI, where the dominant species of Calyptogena are C. soyoae and C. okutanii, respectively (Table 2).

The shell length-height ratio of Calyptogena with shell length less than $62.3 \mathrm{~mm}$ was below 2.09 (Fig. 4). Therefore, based on the length-height ratio, small C. okutanii tends to be classified as C. soyoce. Kojima \& Ohta (1997b) stated that it is impossible to discriminate accu- 
rately between $C$. soyoae and $C$. okutanii based solely on the shell length-height ratio because the ratios of the species overlap. The overlap may be due to growth-related changes in shell shape. To detect the species composition accurately, molecular analysis (or more stable key characteristics for classification) will be needed.

Most ecological studies of the genus Calyptogena in Sagami Bay have been conducted at the OHI cold-seepage site; reports have provided descriptions of the habitat and colonies (Okutani \& Egawa 1985; Hashimoto et al. 1989, 1995) and lifehistory characteristics such as growth, metamorphosis (Horikoshi \& Hashimoto 1992; Hattori et al. 1993), and reproduction (Momma et al. 1995; Fujiwara et al. 1998). In these studies, all Calyptogena species from $\mathrm{OHI}$ were treated as $C$. soyoae. According to our data, however, $74.4 \%$ of the Calyptogena species at $\mathrm{OHI}$ are $C$. okutanii (Table 2). Therefore, most of the ecological information on the Calyptogena species in Sagami Bay has been derived almost exclusively from C. okutanii. In contrast, ecological information on Calyptogena from SK has been derived predominantly from $C$. soyoae, given that more than $90 \%$ of the Calyptogena at this site are C. soyoae (Hattori et al. 1993).

In conclusion, the species composition of Calyptogena in Sagami Bay differed from that in the local coldseepage areas; the dominant species of Calyptogena at $\mathrm{OHI}$ and $\mathrm{OB}$ was $C$. okutanii, and that at SK was $C$. soyoae. Ecological information on Calyptogena in Sagami Bay is derived predominantly from C. okutanii, given that most ecological studies have been conducted at OHI. To determine the causes of differences in species composition among cold-seepage areas, additional field surveys are needed, especially at SK.

Acknowledgments. I am grateful to the operating teams of the Shinkai 2000, Shinkai 6500, and Dolphin $3 K$ submersibles and to the officers and crew of the tender ships Natsushima and Yokosuka of the Japan Marine Science and Technology Center (JAMSTEC) for their help in collecting samples. I thank Dr. Hashimoto for his kind advice, suggestions, and critical reading of the manuscript. I also thank Drs. S. Kojima, J. Fujikura, and Y. Fujiwara for their kind advice and suggestions. Ms. $\mathrm{H}$. Nakamura, E. Suzuki, and K. Yamamoto provided a great deal of help with the maintenance of specimens.

\section{REFERENCES}

Barry, J. P., R. E. Kochevar and C. H. Baxter 1997. The influence of pore-water chemistry and physiology on the distribu- tion of vesicomyid clams at cold seeps in Monterey Bay: implications for patterns of chemosynthetic community organization. Limnology and Oceanography, 42: 318-328.

Endow, K. and S. Ohta 1990. Occurrence of bacteria in the primary oocytes of vesicomyid clam Calyptogena soyoae. Marine Ecology Progress Series, 64: 309-311.

Fujiwara, Y., J. Tsukahara, J. Hashimoto and K. Fujikura 1998. In situ spawning of a deep-sea vesicomyid clam: evidence for an environmental cue. Deep-Sea Research I, 45: 18811889.

Hashimoto, J., S. Matsuzawa and H. Hotta 1988. Searching for biological communities at the Okinoyama Bank Site, the Sagami Bay. Proceedings of JAMSTEC Symposium on Deep Sea Research, 4: 177-188. (in Japanese with English abstract)

Hashimoto, J., S. Ohta, K. Fujikura, Y. Fujiwara and S. Sukizaki 1995 Life habit of vesicomyid clam, Calyptogena soyoae, and hydrogen sulfide concentration in interstitial waters in Sagami Bay, Japan. Journal of Oceanography, 51: $341-350$

Hashimoto, J., S. Ohta, T. Tanaka, H. Hotta, S. Matsuzawa and H. Sakai 1989. Deep-sea communities dominated by the giant clam, Calyptogena soyoae, along with slope foot of Hatsushima Island, Sagami Bay, central Japan. Palaeogeography, Palaeoclimatology, Palaeoecology, 71: 179-192.

Hattori, M., Y. Kanie, J. Hashimoto and K. Fujikura 1993. Geological settings, mode of life and morphology of genus $\mathrm{Ca}$ lyptogena along the subduction zone of the Sagami and Suruga Troughs, central Japan. Proceedings of JAMSTEC Symposium on Deep Sea Research, 9: 237-251. (in Japanese with English abstract)

Horikoshi, M. and J. Hashimoto 1992. Two distinct growth stages of a deep-sea, giant white clam, "Calyptogena" soyoae, and its allied species. Extrait de La Mer, 30: 73-82.

Kojima, S. 2002. Deep-sea chemoautosynthesis-based communities in the northwestern Pacific. Journal of Oceanography, 58: 343-363.

Kojima, S., J. Hashimoto and S. Ohta 1995a The distribution and the phylogenies of the species of genus Calyptogena and those of vestimentiferans around Japan. JAMSTEC Journal of Deep-Sea Research, 11: 243-248. (in Japanese with English abstract)

Kojima, S., R. Segawa, T. Kobayashi, T. Hashimoto, K. Fujikura, J. Hashimoto and S. Ohta 1995b. Phylogenetic relationships among species of Calyptogena (Bivalvia: Vesicomyidae) collected around Japan revealed by nucleotide sequences of mitochondrial genes. Marine Biology, 122: 401407.

Kojima, S. and S. Ohta 1997a. Bathymetrical distribution of the species of the genus Calyptogena in the Nankai Trough, Japan. Venus, 56: 293-297.

Kojima, S. and S. Ohta 1997b. Calyptogena okutanii n. sp., a sibling species of Calyptogena soyoae Okutani, 1957 (Bivalvia: Vesicomyidae). Venus, the Japanese Journal of Malacology, 56: 189-195.

Lisin, S. E., E. E. Hannan, R. E. Kochevar, C. Harrold and J. P. Barry 1997. Temporal variation in gametogenetic cycles of vesicomyid clams. Invertebrate Reproduction and Develop- 
ment, 31: 307-318.

Lutz, R. A. 1993. Ecology of deep-sea hydrothermal vent communities: a review. Review of Geophysics, 31: 211-242.

Momma, H., K. Mitsuzawa, Y. Kaiho, R. Iwase and Y. Fujiwara 1995. Long-term deep sea floor observation off Hatsushima Island in Sagami Bay: one year in the Calyptogena soyoae clam colony. JAMSTEC Journal of Deep Sea Research, 11: 249-268. (in Japanese with English abstract)

Okutani, T. 1957. Two new species of bivalves from the deep water in Sagami Bay collected by the R.V. Soya-Maru. Bulletin of the Tokai Regional Fisheries Research Laboratory, 17: $27-30$.
Okutani, T. and K. Egawa 1985. The first underwater observation on living habit and thanatocoenses of Calyptogena soyoae in bathyal depth of Sagami Bay. Venus, 44: 285-289.

Okutani, T., K. Fujikura and S. Kojima 2000. New taxa and review of vesicomyid bivalves collected from the northwest Pacific by deep sea research systems of Japan Marine Science and Technology Center. Venus, 59: 83-101.

Turekian, K. K. and J. K. Cochran 1981 Growth rate of a vesicomyid clam from the Galápagos spreading center. Science, 214: 909-911.

Zar, J. H. 1999. Biostatistical Analysis (4th ed). Prentice Hall, Upper Saddle River, New Jersey, 663 pp. 